\title{
The correlation of retinol-binding protein-4 and lipoprotein combine index with the prevalence and diagnosis of acute coronary syndrome
}

\author{
Yueqiao $\mathrm{Si}^{1} \cdot$ Jingyi Liu ${ }^{1} \cdot$ Chao Han $^{1} \cdot$ Ruijuan Wang $^{1} \cdot$ Tong Liu $^{1} \cdot$ Lixian Sun ${ }^{1} \mathbb{C}$
}

Received: 19 February 2020 / Accepted: 15 May 2020 / Published online: 24 May 2020

(c) The Author(s) 2020

\begin{abstract}
Retinol-binding protein-4 (RBP-4) along with the lipid profile plays crucial roles in Acute coronary syndrome (ACS). The study aimed to investigate the correlation of RBP-4, lipoprotein combine index (LCI), and RBP-4+LCI with ACS. 163 ACS and 77 non-CAD in patients were consecutively enrolled in this study. The serum level of RBP-4 was measured via enzyme-linked immunosorbent assay. LCI was calculated using the formula: total cholesterol $\times$ triglyceride $\times$ low-density lipoprotein cholesterol/high-density lipoprotein cholesterol. RBP-4 $\geq 4 \mathrm{ng} / \mathrm{ml}, \mathrm{LCI} \geq 16$ and LCI $\geq 16+\mathrm{RBP}-4 \geq 4 \mathrm{ng} / \mathrm{ml}$ were new independent risk factors of ACS, and OR value of LCI $\geq 16+$ RBP- $4 \geq 4 \mathrm{ng} / \mathrm{ml}$ was higher than that of RBP-4 and LCI combined (all $p<0.05$ ). The AUC for LCI + RBP-4 was higher than that for LCI and RBP-4 individually. The risk of high LCI in 1 lesion vessel was greater than those of 2 or $\geq 3$ lesion vessels (all $p<0.05$ ). In 1 lesion vessel or $\geq 3$ lesion vessels group, the risk associated with LCI and RBP-4 combined was higher than the risk of LCI or RBP-4 alone (all $p<0.05$ ). The risk of hypertension, diabetes mellitus, smoking and history of MI increased with numbers of vessels lesion (all $p<0.05$ ). Increase in RBP-4 and LCI values were found to be independent risk factors for ACS, and the risk of the combined rise in LCI and RBP-4 values was higher than LCI or RBP-4 alone. The combined tests of LCI and RBP-4 might be a potential diagnostic marker for ACS.
\end{abstract}

Keywords Acute coronary syndrome $\cdot$ Retinol-binding protein- $4 \cdot$ Lipoprotein combine index $\cdot$ Risk factor

\section{Introduction}

Coronary artery disease (CAD) is one of the most common causes of death worldwide, and it is responsible for more than twice the number of deaths due to cancer $[1,2]$. Acute coronary syndrome (ACS) is caused due to the rupture of atherosclerotic plaques and complete or incomplete thrombosis of the coronary arteries, which is the main part of CAD [3]. Retinol-binding protein-4 (RBP-4) is a novel adipokine or hepatocytic cytokine, and its high serum levels have been associated with insulin resistance and obesity. In fact, elevated RBP-4 levels were found to be a new risk factor for cardiovascular disease [4-7]. Recently, non-traditional lipid profiles have attracted the attention of researchers, and it has been seen that the lipoprotein combine index (LCI) is higher

Lixian Sun

lixiansun01@126.com

1 Department of Cardiology, The Affiliated Hospital of Chengde Medical University, Chengde 067000, Hebei, China in CAD patients than non-CAD patients. However, it is still controversial whether LCI can be established as a new risk predictor for ACS and further research is needed to clarify this [8-10]. Previous studies have reported that RBP-4 is an HDL-associated protein and it is correlated with adverse lipid profiles $[11,12]$. In this study, we hypothesized that RBP-4 + LCI is a better diagnostic predictor of ACS than RBP-4 and LCI alone.

\section{Methods \\ Participants}

A total of 240 inpatients with the suspected ACS were consecutively enrolled for this study from January 2016 to May 2017 at The Affiliated Hospital of Chengde Medical College. They were divided into two groups after coronary angiography (CAG), ACS group $(n=163)$ and non-CAD group $(n=77)$. The Inclusion Criteria for ACS group included age $\geq 18$ years; unstable angina; non-ST elevation myocardial 
infarction; and ST-elevation myocardial infarction [13]; CAG: the stenosis at least or more than $50 \%$ in one or more of the left main, left anterior descending, left circumflex, right coronary, or their main branches. The Inclusion Criteria for the non-CAD group included age $\geq 18$ years; suspected ACS without any stenosis of coronary arteries or stenosis less than $50 \%$ of the left main, left anterior descending, left circumflex, right coronary, or their main branches. The Exclusion Criteria for both ACS group and non-CAD group included infectious diseases, malignant tumors, immune system diseases, connective tissue disease, severe valvular heart disease, aortic dissection, constrictive pericarditis, hypertrophic cardiomyopathy and pregnancy. This study was carried out in accordance with the World Medical Association's Code of Ethics (Helsinki Declaration), and approved by the Institutional Review Boards of The Affiliated Hospital of Chengde Medical University. All subjects provided written informed consent.

\section{Demographic and clinical data}

The baseline characteristics of the demographic and clinical data included the age, gender, height and weight, systolic blood pressure, diastolic blood pressure, the circulation level of total cholesterol (TC), triglyceride (TG), low-density lipoprotein cholesterol (LDL-C), and high-density lipoprotein cholesterol (HDL-C). The risk factors for ACS such as diabetes, hypertension, dyslipidemia and ischemic stroke were carefully noted. Following this, the LCI [10] was calculated using the formula, $\mathrm{TC} \times \mathrm{TG} \times$ LDL-C/HDL-C.

\section{Enzyme-linked immunosorbent assay}

Peripheral blood samples of all the subjects were taken from the antecubital vein after overnight fasting and prior to CAG. The blood samples were allowed to stand for $30 \mathrm{~min}$ and centrifuged at $5000 \mathrm{~g}$ for $10 \mathrm{~min}$. Then, the serum was aliquoted and stored at $-80{ }^{\circ} \mathrm{C}$ until further use. The serum level of RBP-4 was measured using an enzyme-linked immunosorbent assay (ELISA) kit.

\section{Statistical analysis}

Statistical analyses were performed using Statistical Package for Social Sciences, version 19 (SPSS Inc., Chicago, IL, USA) software. Kolmogorov-Smirnov test was used to analyze all continuous data with normal or skewed distribution. Mean \pm standard deviation and quartile $\mathrm{M}(\mathrm{QR})$ were used to express normal and skewed continuous data, respectively. The categorical data were expressed as percentages. Differences in the patient characteristics between the ACS group and non-CAD group were tested with Mann-Whitney $U$ test for continuous variables and Chi square testing was used for categorical variables. The receiver operation characteristic (ROC) curve was used to determine the best diagnostic cutoff point for RBP-4 and LCI, as well as the AUC of RBP-4, LCI and RBP-4+LCI. All the categorical variables were analyzed using univariate logistic regression analysis, then, variables with $p<0.05$ obtained from the univariate analysis were included in the multivariate logistic regression analysis and multinomial logistic regression analysis. Multivariate logistic regression model 1 and 2 were established by adjusted RBP4, LCI, and RBP-4 + LCI. Multinomial logistic regression analysis model was established based on 4 groups according to the number of lesion vessels, and then, the RBP-4, LCI and RBP-4 + LCI values were adjusted to establish the models 1 , 2 and 3 . The level of significance for all the analyses was set at $p<0.05$.

\section{Results}

\section{Baseline characteristics of the ACS group and non-CAD group}

The mean age and BMI as well as the number of subjects with smoking history were significantly higher in the ACS group than in the non-CAD group (all $p<0.05$ ). Chest pain and abnormal wall motion were more common in the ACS group than non-CAD group (both $p<0.05$ ). Compared to the non-CAD group, the morbidity due to myocardial infarction, dyslipidemia, hypertension, and diabetes mellitus were significantly higher in the ACS group (all $p<0.05$ ). The serum lipid profiles of the patients in the ACS group showed significantly higher TC, TG and LDL-C levels than those in the non-CAD group (all $p<0.05$ ). Yet, there was no significant difference between the two groups in terms of the HDL-C level and the prevalence of ischemic stroke (both $p>0.05$ ). In the ACS group, the prevalence of RBP- $4 \geq 4 \mathrm{ng} / \mathrm{ml}$, LCI $\geq 16$, RBP- $4 \geq 4 \mathrm{ng} / \mathrm{ml}+\mathrm{LCI} \geq 16$ were significantly higher than non-CAD group (all $p<0.05$ ). Moreover, the number of patients with 1,2 and $\geq 3$ lesion vessels in the ACS group were 53, 48 and 62 , respectively (Table 1 ).

The RBP-4 levels and the LCI values were significantly higher in the ACS group than the non-CAD group (Fig. 1). Compared to the 4 groups with different numbers of lesion vessels, the RBP-4 level increased with an increase in the number of lesion vessels. The LCI value was significantly higher in patients with lesion vessels than patients without lesion vessels, with the highest being in the group with 1 lesion vessel (Fig. 2).

\section{Receiver-operating characteristic curve analyses of ACS group and non-CAD group subjects}

The AUC of the RBP-4 was 0.754 (95\% CI $0.638-0.825$, $p<0.001)$. The optimal diagnostic cut off point for RBP-4 
Table 1 Baseline characteristics of the ACS group and non-CAD group
Fig. 1 a The level of RBP-4 in ACS group and Non-CAD group, $\mathbf{b}$ the value of LCI in the ACS group and non-CAD group

\begin{tabular}{|c|c|c|c|c|}
\hline Variables & ACS group $(n=163)$ & Non-CAD group $(n=77)$ & $\chi^{2} / Z$ & $p$ \\
\hline Male & $120(73.6)$ & $49(63.6)$ & 1.595 & 0.114 \\
\hline Age (years) & $60 \pm 10$ & $57 \pm 10$ & 2.223 & 0.027 \\
\hline BMI $\left(\mathrm{kg} / \mathrm{m}^{2}\right)$ & $25.5 \pm 2.4$ & $24.6 \pm 2.4$ & 2.343 & 0.020 \\
\hline Smoking (\%) & $99(60.7)$ & $28(36.4)$ & 2.707 & $<0.001$ \\
\hline Family history of CAD (\%) & $38(23.3)$ & $14(18.2)$ & 1.368 & 0.368 \\
\hline History of MI (\%) & $51(31.3)$ & $3(3.9)$ & 11.232 & $<0.001$ \\
\hline Abnormal heart wall motion (\%) & $93(59.2)$ & $19(26.8)$ & 3.977 & $<0.001$ \\
\hline Chest pain $(\%)$ & $138(84.7)$ & $20(26.0)$ & 15.732 & $<0.001$ \\
\hline Dyslipidemia (\%) & $74(45.4)$ & $15(19.5)$ & 3.437 & $<0.001$ \\
\hline Hypertension (\%) & $111(68.1)$ & $40(51.9)$ & 1.975 & 0.016 \\
\hline Diabetes mellitus (\%) & $64(39.3)$ & $15(19.5)$ & 2.672 & 0.002 \\
\hline Ischemic stroke (\%) & $33(20.2)$ & $14(18.2)$ & 1.142 & 0.707 \\
\hline Systolic blood pressure (mmHg) & $136(123,160)$ & $136(121,145)$ & -1.619 & 0.105 \\
\hline Diastolic blood pressure $(\mathrm{mmHg})$ & $81(75,90)$ & $80(75,90)$ & -0.057 & 0.955 \\
\hline $\mathrm{TC}(\mathrm{mmol} / \mathrm{l})$ & $4.2 \pm 1.0$ & $3.9 \pm 0.9$ & 2.009 & 0.046 \\
\hline TG (mmol/l) & $1.7(1.2,2.5)$ & $1.4(1.1,2.1)$ & -2.007 & 0.038 \\
\hline LDL-C (mmol/l) & $2.1 \pm 0.9$ & $1.9 \pm 0.8$ & 2.231 & 0.027 \\
\hline HDL-C (mmol/l) & $1.0(0.9,1.2)$ & $1.1(0.9,1.3)$ & -1.125 & 0.260 \\
\hline \multicolumn{5}{|l|}{ Coronary angiography } \\
\hline 1 vessel (\%) & $53(32.5)$ & - & - & - \\
\hline 2 vessels $(\%)$ & $48(29.4)$ & - & - & - \\
\hline$\geq 3$ vessels $(\%)$ & $602(36.8)$ & - & - & - \\
\hline RBP-4 $\geq 4$ ng/ml (\%) & $136(83.4)$ & $33(42.9)$ & 6.716 & $<0.001$ \\
\hline $\mathrm{LCI} \geq 16(\%)$ & $78(47.9)$ & $19(24.7)$ & 2.801 & 0.001 \\
\hline $\mathrm{RBP}-4 \geq 4 \mathrm{ng} / \mathrm{ml}+\mathrm{LCI} \geq 16(\%)$ & $69(42.3)$ & 10 (13.0) & 4.918 & $<0.001$ \\
\hline
\end{tabular}

Data presented as number (\%) of patients, median (interquartile range)

$B M I$ body mass index, $M I$ myocardial infarction, $T C$ total cholesterol, $T G$ triglyceride, $L D L-C$ low-density lipoprotein cholesterol, $H D L-C$ high-density lipoprotein cholesterol, $R B P-4$ retinol-binding protein 4
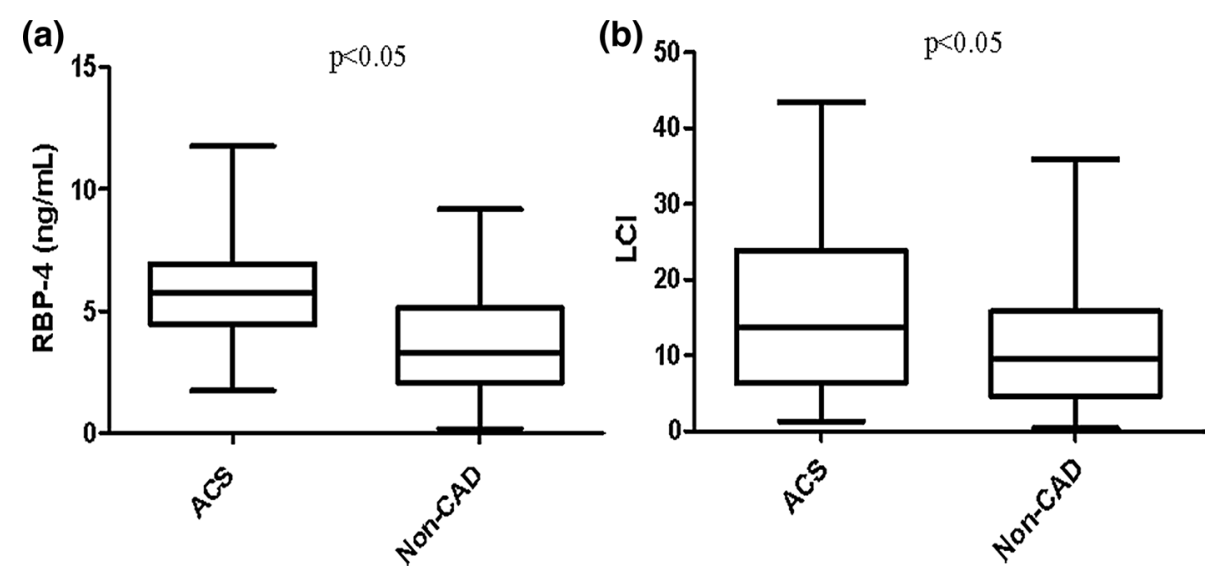

was $4 \mathrm{ng} / \mathrm{ml}$. The sensitivity and the specificity were 84 and $57 \%$, respectively. The AUC of the LCI was 0.608 (95\% CI $0.532-0.683, p=0.007)$. The optimal diagnostic cut off point for LCI was $16 \mathrm{ng} / \mathrm{ml}$, and the sensitivity and the specificity were 48 and $75 \%$, respectively. The
AUC of the LCI + RBP-4 was 0.761 (95\% CI 0.691-0.830, $p<0.001$ ), and the sensitivity and the specificity were 83 and 58\%, respectively. Surprisingly, the AUC of the LCI + RBP-4 was higher than the AUC of the LCI and RBP-4 (Table 2; Fig. 3). 




Fig. 2 The level of RBP-4 and the value of LCI among the lesion vessels group with varying lesion numbers

\section{Multiple logistic regression of ACS risk factors}

Multivariate logistic regression model 1 analysis showed that hypertension, diabetes mellitus, smoking, history of MI, RBP- $4 \geq 4 \mathrm{ng} / \mathrm{ml}$ and LCI $\geq 16$ were independent risk factors of ACS, and the odds ratio (OR) of these factors were 2.284 (1.123, 4.644), 2.716 (1.251, 5.899), 4.082 (1.996, $8.345), 10.102$ (2.803, 36.404), 4.435 (2.202, 8.931) and $2.496(1.209,5.154)$, respectively (all $p<0.05)$. Multivariate logistic regression model 2 analysis showed that hypertension, diabetes mellitus, smoking, history of MI and LCI $\geq 16+\mathrm{RBP}-4 \geq 4 \mathrm{ng} / \mathrm{ml}$ were independent risk factors of ACS, the odds ratio (OR) of these factors were 2.546 (1.282, 5.054), 3.185 (1.490, 6.808), 4.076 (2.043, 8.130), 12.305 $(3.514,43.087)$ and $5.299(2.348,11.957)$, respectively (all $p<0.05)$. The OR value of the history of MI was the highest among those risk factors in the two models. RBP-4 $\geq 4 \mathrm{ng} /$ $\mathrm{ml}, \mathrm{LCI} \geq 16$ and LCI $\geq 16+\mathrm{RBP}-4 \geq 4 \mathrm{ng} / \mathrm{ml}$ were all new independent risk factors of ACS. In addition, the OR value of LCI $\geq 16+\mathrm{RBP}-4 \geq 4 \mathrm{ng} / \mathrm{ml}$ was higher than the OR value of RBP-4 $\geq 4 \mathrm{ng} / \mathrm{ml}$ and LCI $\geq 16$. (Table 3 ).

\section{Multinomial logistic regression model for risk factors of different number of lesion vessels}

To investigate the strength of the association between different lesion vessels and the factors such as RBP-4, LCI, and RBP-4 + LCI, we established multinomial logistic regression analysis model 1, 2, 3 with adjusted RBP-4, LCI and RBP-4 + LCI, respectively. Smoking, history of MI, RBP-4 $\geq 4 \mathrm{ng} / \mathrm{ml}$, LCI $\geq 16$ and RBP-4 + LCI were found to be independent risk factors of 1 lesion vessel; hypertension, diabetes mellitus, smoking, history of MI, RBP-4 $\geq 4 \mathrm{ng} /$ $\mathrm{ml}$, LCI $\geq 16$ and RBP-4 + LCI were independent risk factors of 2 lesion vessels; and finally, hypertension, diabetes mellitus, smoking, history of MI, RBP-4 $\geq 4 \mathrm{ng} / \mathrm{ml}$, LCI $\geq 16$ and RBP-4 + LCI were independent risk factors of 3 lesion vessels (all $p<0.05$ ).

In the 1 lesion vessel group and $\geq 3$ lesion vessels group, the odds ratio (OR) of $\mathrm{LCI} \geq 16+\mathrm{RBP}-4 \geq 4 \mathrm{ng} / \mathrm{ml}$ were higher than the odds ratio (OR) of LCI $\geq 16$ or RBP- $4 \geq 4 \mathrm{ng}$ / $\mathrm{ml}$ alone. However, in 2 lesion vessels group, the odds ratio (OR) of RBP-4 $\geq 4 \mathrm{ng} / \mathrm{ml}$ was higher than the odds ratio (OR) of LCI $\geq 16+$ RBP- $4 \geq 4 \mathrm{ng} / \mathrm{ml}$ and LCI $\geq 16$. In addition, multinomial logistic regression models $1,2,3$ for risk factors of 1, 2, 3 lesion vessels group showed that the odds ratio (OR) of hypertension, diabetes mellitus, smoking and
Table 2 ROC curve analyses of the ACS group and non-CAD group

\begin{tabular}{llllllll}
\hline Variable & AUC & \multicolumn{1}{l}{ SE } & \multicolumn{1}{l}{$p$} & \multicolumn{1}{l}{$95 \%$ CI } & Se $(\%)$ & Sp (\%) & Cut off \\
\hline RBP-4 & 0.754 & 0.036 & $<0.001$ & $0.638-0.825$ & 84 & 57 & 4 \\
LCI & 0.608 & 0.038 & 0.007 & $0.532-0.683$ & 48 & 75 & 16 \\
LCI+RBP-4 & 0.761 & 0.036 & $<0.001$ & $0.691-0.830$ & 83 & 58 & - \\
\hline
\end{tabular}

$A U C$ area under curve, $R B P-4$ retinol-binding protein $4, L C I$ lipoprotein combine index

(a)

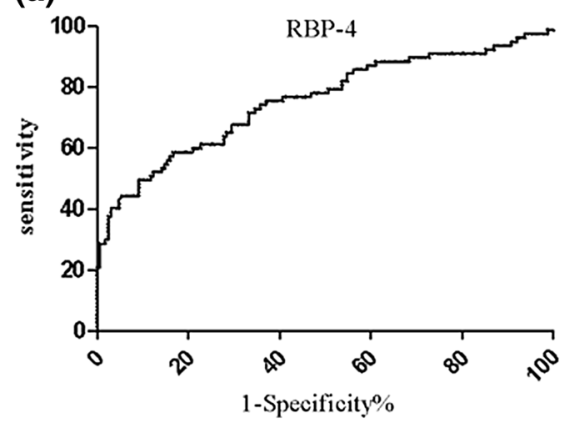

(b)

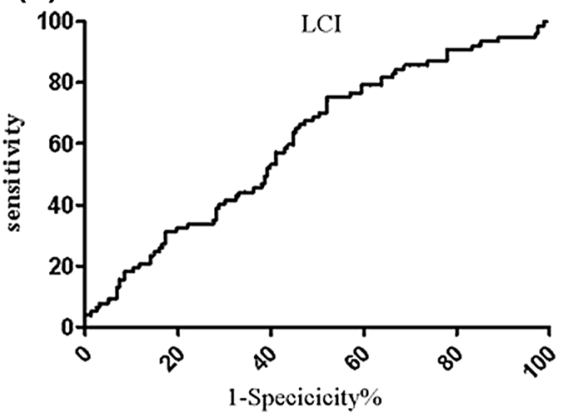

(c)

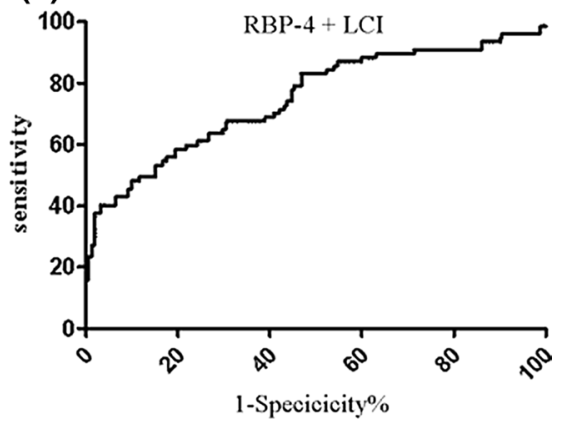

Fig. 3 a Receiver operation characteristic (ROC) curve of RBP-4, b ROC curve of LCI, and $\mathbf{c}$ ROC curve of RBP4+LCI 
Table 3 Multiple logistic regression of ACS risk factors

\begin{tabular}{|c|c|c|c|c|c|c|}
\hline \multirow[t]{2}{*}{ Variable } & \multicolumn{3}{|c|}{ Model 1} & \multicolumn{3}{|c|}{ Model 2} \\
\hline & OR & $95 \% \mathrm{CI}$ & $p$ & OR & $95 \% \mathrm{CI}$ & $p$ \\
\hline Hypertension & 2.284 & $1.123-4.644$ & 0.023 & 2.546 & $1.282-5.054$ & 0.008 \\
\hline Diabetes mellitus & 2.716 & $1.251-5.899$ & 0.012 & 3.185 & $1.490-6.808$ & 0.003 \\
\hline Smoking & 4.082 & $1.996-8.345$ & $<0.001$ & 4.076 & $2.043-8.130$ & $<0.001$ \\
\hline History of MI & 10.102 & $2.803-36.404$ & $<0.001$ & 12.305 & $3.514-43.087$ & $<0.001$ \\
\hline $\mathrm{RBP}-4 \geq 4 \mathrm{ng} / \mathrm{ml}$ & 4.435 & $2.202-8.931$ & $<0.001$ & - & - & $<0.001$ \\
\hline $\mathrm{LCI} \geq 16$ & 2.496 & $1.209-5.154$ & 0.013 & - & - & 0.013 \\
\hline $\mathrm{LCI} \geq 16+\mathrm{RBP}-4 \geq 4 \mathrm{ng} / \mathrm{ml}$ & - & - & - & 5.299 & $2.348-11.957$ & $<0.001$ \\
\hline
\end{tabular}

$M I$ myocardial infarction, $R B P-4$ retino-binding protein 4, $L C I$ lipoprotein combine index history of MI increased with the increase in the number of causing lesion vessels (Table 4).

\section{Discussion}

In this cross-sectional study, we discovered that a combination of the RBP-4 level and the LCI value can be used to diagnose ACS and found that RBP-4 + LCI was a novel independent risk factor for ACS. The main findings of this study are as follows: First, per ROC curve analysis, the AUC of the LCI+ RBP-4 group was higher than the AUC of the individual LCI and RBP-4 groups, and this indicated that the accuracy of ACS diagnosis using combined RBP-4 + LCI values was higher than the accuracy of RBP-4 or LCI alone. Second, RBP- $4 \geq 4 \mathrm{ng} / \mathrm{ml}, \mathrm{LCI} \geq 16$ and LCI $\geq 16+$ RBP- 4 $\geq 4 \mathrm{ng} / \mathrm{ml}$ were all new independent risk factors of ACS besides the classical risk factors of CAD. Interestingly, the risk associated with $\mathrm{LCI} \geq 16+\mathrm{RBP}-4 \geq 4 \mathrm{ng} / \mathrm{ml}$ was higher than the risk of LCI $\geq 16$ or RBP- $4 \geq 4 \mathrm{ng} / \mathrm{ml}$ alone. Third, the risk of RBP- $4 \geq 4 \mathrm{ng} / \mathrm{ml}$ for the occurrence of lesion 2 vessels is highest, while the risk of LCI $\geq 16$ for the occurrence of 1 lesion vessel is highest. There is growing evidence supporting that the presence and severity of the cardiovascular disease can be detected using certain biomarkers and components of the lipid profile. However, to our knowledge, this is the first study that has reported the association among LCI $\geq 16$, RBP and ACS [14-16].

There is increasing data strongly supporting the fact that the serum level of RBP-4 is associated with cardiovascular disease as well as adverse cardiovascular outcomes [17, 18]. Liu et al. [19] conducted a cross-sectional and prospective study, which reported that the level of RBP-4 is significantly associated with the complexity of coronary lesion in patients with ACS. A cross-sectional study by Lambadiari et al. [20] found that RBP-4 is a strong predictor of CAD,

Table 4 Multinomial logistic regression model for risk factors of different number of vascular lesions

\begin{tabular}{|c|c|c|c|c|c|c|c|c|c|c|}
\hline \multirow[t]{2}{*}{ Variable } & & \multicolumn{3}{|c|}{1 lesion vessel } & \multicolumn{3}{|c|}{2 lesion vessels } & \multicolumn{3}{|c|}{$\geq 3$ lesion vessels } \\
\hline & & OR & $95 \% \mathrm{CI}$ & $p$ & OR & $95 \% \mathrm{CI}$ & $p$ & OR & $95 \% \mathrm{CI}$ & $p$ \\
\hline \multirow[t]{5}{*}{ Model 1} & Hypertension & 1.153 & $0.529-2.513$ & 0.721 & 2.442 & $1.009-5.907$ & 0.048 & 2.876 & $1.214-6.816$ & 0.016 \\
\hline & Diabetes mellitus & 2.067 & $0.848-5.034$ & 0.110 & 3.936 & $1.594-9.717$ & 0.003 & 4.718 & $1.969-11.306$ & 0.001 \\
\hline & Smoking & 3.323 & $1.498-7.373$ & 0.003 & 3.390 & $1.438-7.995$ & 0.005 & 3.503 & $1.528-8.027$ & 0.003 \\
\hline & History of MI & 4.559 & $1.325-15.691$ & 0.016 & 6.068 & $1.728-21.310$ & 0.005 & 9.876 & $2.946-33.116$ & $<0.001$ \\
\hline & $\mathrm{RBP}-4 \geq 4 \mathrm{ng} / \mathrm{ml}$ & 3.643 & $1.597-8.309$ & 0.002 & 6.587 & $2.385-18.197$ & $<0.001$ & 4.749 & $1.902-11.859$ & 0.001 \\
\hline \multirow[t]{5}{*}{ Model 2} & Hypertension & 1.384 & $0.638-3.002$ & 0.411 & 2.983 & $1.256-7.084$ & 0.013 & 3.453 & $1.475-8.082$ & 0.004 \\
\hline & Diabetes mellitus & 1.862 & $0.756-4.584$ & 0.177 & 3.711 & $1.517-9.077$ & 0.004 & 4.448 & $1.861-10.635$ & 0.001 \\
\hline & Smoking & 3.434 & $1.552-7.601$ & 0.002 & 3.458 & $1.498-7.893$ & 0.004 & 3.584 & $1.586-8.097$ & 0.002 \\
\hline & History of MI & 6.628 & $1.952-22.505$ & 0.002 & 9.355 & $2.724-32.130$ & $<0.001$ & 14.575 & $4.417-48.092$ & $<0.001$ \\
\hline & $\mathrm{LCI} \geq 16$ & 3.627 & $1.637-8.036$ & 0.002 & 2.993 & $1.292-6.934$ & 0.011 & 2.884 & $1.269-6.554$ & 0.011 \\
\hline \multirow[t]{5}{*}{ Model 3} & Hypertension & 1.360 & $0.621-2.978$ & 0.128 & 2.954 & $1.230-7.092$ & 0.015 & 3.413 & $1.445-8.062$ & 0.005 \\
\hline & Diabetes mellitus & 2.020 & $0.818-4.990$ & 0.128 & 3.887 & $1.579-9.572$ & 0.003 & 4.672 & $1.944-11.244$ & 0.001 \\
\hline & Smoking & 3.516 & $1.573-7.859$ & 0.002 & 3.565 & $1.526-8.326$ & 0.003 & 3.679 & $1.613-8.393$ & 0.002 \\
\hline & History of MI & 6.182 & $1.811-21.107$ & 0.004 & 8.865 & $2.559-30.707$ & 0.001 & 13.847 & $4.168-46.003$ & $<0.001$ \\
\hline & $\mathrm{LCI}+\mathrm{RBP}-4$ & 5.863 & $2.308-13.991$ & $<0.001$ & 5.494 & $2.140-14.105$ & $<0.001$ & 4.996 & $1.974-12.641$ & 0.001 \\
\hline
\end{tabular}

$M I$ myocardial infarction, $R B P-4$ retinol-binding protein 4, $L C I$ lipoprotein combine index 
and independently correlated its levels with CAD severity. Both these conclusions are consistent with our results. Additionally, our findings also extend the reports of these previous studies by showing that the level of RBP-4 showed an upward trend with the increase in the number of lesions in the vessels, and the risk of RBP- $4 \geq 4 \mathrm{ng} / \mathrm{ml}$ for occurrence of 2 vessels lesion was the highest compared to 1 or $\geq 3$ vessels lesion group. Recent studies have demonstrated that RBP-4 contributes to inflammatory injury of cardiomyocytes through Toll-like receptor 4 activation and myeloid differentiation through the primary response gene 88 (MyD88) pathway [21]. Additionally, pathophysiological mechanism of insulin resistance, type 2 diabetes, and endothelial dysfunction occurs through extracellular signal-regulated kinase activity $[7,22,23]$.

The patients with ACS had higher levels of TC, TG, LDL-C and lower level of HDL-C than those in the control group in previous studies [24, 25]. There is evidence indicating that TC, TG, LDL-C and HDL-C levels could be used as risk markers of cardiovascular disease with a strong correlation with coronary atherosclerosis $[16,26,27]$. However, the HDL-C levels had no statistical difference between the two groups in our study.TG-rich lipoproteins, TG, and LDL-C play roles in promoting inflammation, thrombosis, and insulin resistance, which are related to the formation, development and vulnerability of coronary plaque [28-30]. In addition to participating in reverse cholesterol transport, HDL-C also has antioxidant, anti-inflammatory, and antiatherosclerotic effect [31]. Previous studies have shown that the ratios of TG/HDL-C, TC/HDL-C, LDL-C/HDL-C are significantly associated with insulin resistance [32]. Further, the ratio of TG/HDL-C is related to the severity of CAD and can be used as a significant predictor of ACS in young adults, while non-HDL-C/TC is a new marker to assess the severity of coronary artery lesions and cardiovascular outcomes [26, 33]. Although Wu et al. [10] proposed the importance of LCI value, they did not report LCI as a significant risk predictor of CAD. However, our study has clearly shown that LCI can be used as a risk factor for ACS, and the risk associated with it was similar to the risk of hypertension and diabetes mellitus.

In the past few decades, a large number of studies have been conducted to understand the pathogenesis, clinical prevention and treatment of cardiovascular diseases. Studies have also confirmed that adipose tissues such as epicardial adipose tissue, pericardial adipose tissue, and thoracic adipose tissue secrete adipocytokines such as adiponectin, tumor necrosis factor- $\alpha$ (TNF- $\alpha$ ), and omentin-1. Moreover, the clinical risk factors such as diabetes, hypertension, dyslipidemia are strongly linked with the pathophysiological mechanisms of CAD [14, 34-38]. Although these efforts have improved the screening, diagnosis, treatment, and prognosis of CAD, the prevalence of CAD remains high and it is still one of the major health issues in the world. ACS remains to be the most common cause of death worldwide, and the mortality due to ACS continues to rise [39]. Previous studies have focused on the unilateral effects of adipocytokines or clinical risk factors or adipose tissue on CAD. In this study, we have shown that when the levels adipocytokines such as RBP-4 were combined with clinical markers related to the diagnosis of ACS, the diagnostic accuracy of the combined indicator was higher than that of the single indicator, and the risk associated with the combined indicator was higher than the single indicator. In addition, we have also found that the numbers of stenotic vessels increased with increase in risk factors such as risk of hypertension, diabetes mellitus, smoking and history of MI. These findings might help in further promoting the diagnosis, prevention, and treatment of ACS.

In this study, the risk of LCI $\geq 16$ for the occurrence of 1 lesion vessel was surprisingly higher than the risk of occurrence of 2 or $\geq 3$ lesion vessels. We searched Medline by "lipoprotein combine index" and got three literatures only. A cross- sectional study found that LCI correlated with the atherosclerotic vascular disease better than serum lipid parameters [40]. Stephen et al. found that LCI was a predictive indicator of CAD [10, 41]. However, no literatures above were correlated with LCI and the numbers of stenotic coronary arteries. We are so sorry that the true mechanisms of LCI in coronary artery lesions is still unclear. Therefore, further researches are needed to tell the whole story then.

This study had some limitations. First, the sample size is relatively small, and as a result, there might be a selection bias. Second, as this is a single-center study, all inpatients were enrolled from one hospital within a specific period of time. Hence, a multi-regional and multi-ethnic study with a large sample size is needed in the future. Third, our study only explored the combined effects of RBP-4 and LCI on ACS, and the role of other adipocytokines and clinical risk factors along with these factors need to be further explored.

In conclusion, increase of the RBP-4 and LCI values were found to be independent risk factors for ACS, and the risk associated with the combined rise of LCI and RBP-4 was higher than the risk of LCI or RBP-4 alone. Therefore, combined tests assessing the LCI and RBP-4 values might be a potential diagnostic marker for ACS. However, as a single-center pilot study with a small sample size, the conclusions may have some limitations indeed. Our team will do more research work on ACS territory in the future clinical practice.

Acknowledgements The authors are grateful to the assistance provided by the cardiology and radiology doctors and nurses at The Affiliated Hospital of Chengde Medical University.

Author contributions YS designed the study, performed the research, analyzed data, and wrote the paper. JL, TL and $\mathrm{CH}$ performed the experiments and collected the data. RW carried out the experiments. 
LS designed the study, discussed the results and revised the manuscript. All the authors approved the final version of the manuscript for publication.

Funding This study was supported by grants from Hebei Province Government Science and Technology Agency (Grant no. 17277769D) to Dr. Lixian Sun, and 2019 Hebei Provincial Department of Education Graduate Innovation Funding Project (Grant no.CXZZSS2019133) to Chao Han.

\section{Compliance with ethical standards}

Conflict of interest The authors declare that they have no competing interests.

Open Access This article is licensed under a Creative Commons Attribution 4.0 International License, which permits use, sharing, adaptation, distribution and reproduction in any medium or format, as long as you give appropriate credit to the original author(s) and the source, provide a link to the Creative Commons licence, and indicate if changes were made. The images or other third party material in this article are included in the article's Creative Commons licence, unless indicated otherwise in a credit line to the material. If material is not included in the article's Creative Commons licence and your intended use is not permitted by statutory regulation or exceeds the permitted use, you will need to obtain permission directly from the copyright holder. To view a copy of this licence, visit http://creativecommons.org/licenses/by/4.0/.

\section{References}

1. Roth GA, Huffman MD, Moran AE, Feigin V, Mensah GA, Naghavi M, Murray CJ (2015) Global and regional patterns in cardiovascular mortality from 1990 to 2013. Circulation 132: $1667-1678$

2. GBD 2013 Mortality and Causes of Death Collaborators (2015) Global, regional, and national age-sex specific all-cause and cause-specific mortality for 240 causes of death, 1990-2013: a systematic analysis for the Global Burden of Disease Study 2013. Lancet 385:117-171

3. Sivri S, Sokmen E, Celik M, Ozbek SC, Yildirim A, Boduroglu Y (2019) Usefulness of white blood cell count to mean platelet volume ratio in the prediction of SYNTAX score in patients with non-ST elevation myocardial infarction. Pak J Med Sci 35:824-829

4. Yang Q, Graham TE, Mody N, Preitner F, Peroni OD (2005) Serum retinol binding protein 4 contributes to insulin resistance in obesity and type 2 diabetes. Nature 436:356-362

5. Promintzer M, Krebs M, Todoric J, Luger A, Bischof MG, Nowotny P, Wagner O (2007) Insulin resistance is unrelated to circulating retinol binding protein and protein $\mathrm{C}$ inhibitor. $\mathrm{J}$ Clin Endocrinol Metab 92:4306-4312

6. Majerczyk M, Choreza P, Bozentowicz-Wikarek M, Brzozowska A, Arabzada H, Owczarek A, Mossakowska M, Grodzicki T, Zdrojewski T, Wiecek A, Olszanecka-Glinianowicz M, Chudek J (2017) Increased plasma RBP4 concentration in older hypertensives is related to the decreased kidney function and the number of antihypertensive drugs-results from the PolSenior substudy. J Am Soc Hypertens 11:71-80

7. Moraes-Vieira PM, Castoldi A, Aryal P, Wellenstein K, Peroni OD, Kahn BB (2016) Antigen presentation and T-cell activation are critical for RBP4-induced insulin resistance. Diabetes 65:1317-1327
8. Wang D, Wang L, Wang Z, Chen S, Ni Y, Jiang D (2018) Higher non-HDL-cholesterol to HDL-cholesterol ratio linked with increased nonalcoholic steatohepatitis. Lipids Health Dis 17:67

9. Zhang Y, Wu NQ, Li S, Zhu CG, Guo YL, Qing P, Gao Y, Li XL, Liu G, Dong Q, Li JJ (2016) Non-HDL-C is a better predictor for the severity of coronary atherosclerosis compared with LDL-C. Heart Lung Circ 25:975-981

10. Wu TT, Gao Y, Zheng YY, Ma YT, Xie X (2018) Atherogenic index of plasma (AIP): a novel predictive indicator for the coronary artery disease in postmenopausal women. Lipids Health Dis $17: 197$

11. Alwaili K, Bailey D, Awan Z, Ruel I, Hafiane A, Krimbou L, Laboissiere S, Genest J (2012) The HDL proteome in acute coronary syndromes shifts to an inflammatory profile. Biochim Biophys Acta 1821:405-415

12. von Eynatten M, Lepper PM, Liu D, Lang K, Baumann M, Nawroth PP, Bierhaus A, Dugi KA, Heemann U, Allolio B, Humpert PM (2007) Retinol-binding protein 4 is associated with components of the metabolic syndrome, but not with insulin resistance, in men with type 2 diabetes or coronary artery disease. Diabetologia 50:1930-1937

13. Roffi M, Patrono C, Collet JP, Mueller C, Valgimigli M, Andreotti F, Bax JJ, Borger MA, Brotons C, Chew DP, Gencer B, Hasenfuss G, Kjeldsen K, Lancellotti P, Landmesser U, Mehilli J, Mukherjee D, Storey RF, Windecker S, ESC Scientific Document Group (2016) 2015 ESC guidelines for the management of acute coronary syndromes in patients presenting without persistent ST-segment elevation. Task force for the management of acute coronary syndromes in patients presenting without persistent st-segment elevation of the european society of cardiology (ESC). G Ital Cardiol (Rome) 17:831-872

14. Woodward L, Akoumianakis I, Antoniades C (2017) Unravelling the adiponectin paradox: novel roles of adiponectin in the regulation of cardiovascular disease. Br J Pharmacol 174:4007-4020

15. Gurses KM, Ozmen F, Kocyigit D, Yersal N, Bilgic E, Kaya E, Kopru CZ, Soyal T, Doganci S, Tokgozoglu L, Korkusuz P (2017) Netrin-1 is associated with macrophage infiltration and polarization in human epicardial adipose tissue in coronary artery disease. J Cardiol 69:851-858

16. NCD Risk Factor Collaboration (2019) National trends in total cholesterol obscure heterogeneous changes in HDL and non-HDL cholesterol and total-to-HDL cholesterol ratio: a pooled analysis of 458 population-based studies in Asian and Western countries. Int J Epidemiol. https://doi.org/10.1093/ije/dyz099

17. Calo LA, Maiolino G, Pagnin E, Vertolli U, Davis PA (2014) Increased RBP4 in a human model of activated anti-atherosclerotic and antiremodelling defences. Eur J Clin Invest 44:567-572

18. Wang H, Zhou P, Zou D, Liu Y, Lu X, Liu Z (2018) The role of retinol-binding protein 4 and its relationship with sex hormones in coronary artery disease. Biochem Biophys Res Commun 506:204-210

19. Liu Y, Wang D, Chen H, Xia M (2015) Circulating retinol binding protein 4 is associated with coronary lesion severity of patients with coronary artery disease. Atherosclerosis 238:45-51

20. Lambadiari V, Kadoglou NP, Stasinos V, Maratou E, Antoniadis A, Kolokathis F, Parissis J, Hatziagelaki E, Iliodromitis EK, Dimitriadis G (2014) Serum levels of retinol-binding protein-4 are associated with the presence and severity of coronary artery disease. Cardiovasc Diabetol 13:121

21. Gao W, Wang H, Zhang L, Cao Y, Bao JZ, Liu ZX, Wang LS, Yang Q, Lu X (2016) Retinol-binding protein 4 induces cardiomyocyte hypertrophy by activating TLR4/MyD88 pathway. Endocrinology 157:2282-2293

22. Ram J, Snehalatha C, Selvam S, Nanditha A, Shetty AS, Godsland IF, Johnston DG, Ramachandran A (2015) Retinol binding 
protein-4 predicts incident diabetes in Asian Indian men with prediabetes. BioFactors 41:160-165

23. Solini A, Stea F, Santini E, Bruno RM, Duranti E, Taddei S, Ghiadoni L (2012) Adipocytokine levels mark endothelial function in normotensive individuals. Cardiovasc Diabetol 11:103

24. Carey VJ, Bishop L, Laranjo N, Harshfield BJ, Kwiat C, Sacks FM (2010) Contribution of high plasma triglycerides and low highdensity lipoprotein cholesterol to residual risk of coronary heart disease after establishment of low-density lipoprotein cholesterol control. Am J Cardiol 106:757-763

25. Liu W, Wang T, Sun P, Zhou Y (2019) Expression of Hcy and blood lipid levels in serum of CHD patients and analysis of risk factors for CHD. Exp Ther Med 17:1756-1760

26. Dogan C, Bayram Z, Karagoz A, Bakal RB, Erdogan E, Yilmaz F, Akbal OY, Acar RD, Aktemur T, Guvendi B, Karaduman A, Hakgor A, Kaymaz C, Ozdemir N (2018) Is elevated triglyceride high density lipoprotein cholesterol ratio a risk factor that causes acute coronary syndrome to appear earlier? Bratisl Lek Listy 119:770-775

27. Won KB, Park GM, Yang YJ, Ann SH, Kim YG, Yang DH, Kang JW, Lim TH, Kim HK, Choe J, Lee SW, Kim YH, Kim SJ, Lee SG (2019) Independent role of low-density lipoprotein cholesterol in subclinical coronary atherosclerosis in the absence of traditional cardiovascular risk factors. Eur Heart J Cardiovasc Imaging 20:866-872

28. Urbina EM, Khoury PR, McCoy CE, Dolan LM, Daniels SR, Kimball TR (2013) Triglyceride to HDL-C ratio and increased arterial stiffness in children, adolescents, and young adults. Pediatrics 131:e1082-e1090

29. Salazar MR, Carbajal HA, Espeche WG, Leiva Sisnieguez CE, March CE, Balbin E, Dulbecco CA, Aizpurua M, Marillet AG, Reaven GM (2013) Comparison of the abilities of the plasma triglyceride/high-density lipoprotein cholesterol ratio and the metabolic syndrome to identify insulin resistance. Diab Vasc Dis Res 10:346-352

30. Ozaki Y, Tanaka A, Komukai K, Ishibashi K, Tanimoto T, Kitabata H, Ino Y, Kubo T, Imanishi T, Akasaka T (2013) High-density lipoprotein cholesterol level is associated with fibrous cap thickness in acute coronary syndrome. Circ J 77:2982-2989

31. Welty FK (2013) How do elevated triglycerides and low HDLcholesterol affect inflammation and atherothrombosis? Curr Cardiol Rep 15:400

32. Zhou M, Zhu L, Cui X, Feng L, Zhao X, He S, Ping F, Li W, Li Y (2016) The triglyceride to high-density lipoprotein cholesterol (TG/HDL-C) ratio as a predictor of insulin resistance but not of beta cell function in a Chinese population with different glucose tolerance status. Lipids Health Dis 15:104

33. Huang A, Qi X, Wei L, Zhang M, Zhou S (2019) Non-HDL-c/ TC: a novel lipid-related marker in the assessment of severity of coronary artery lesions and cardiovascular outcomes. Cardiol Res Pract 2019:5931975

34. Morales-Portano JD, Peraza-Zaldivar JA, Suarez-Cuenca JA, Aceves-Millán R, Amezcua-Gómez L, Ixcamparij-Rosales CH, Trujillo-Cortés R, Robledo-Nolasco R, Mondragón-Terán P, Pérez-Cabeza de Vaca R, Hernández-Muñoz R, Melchor-López A, Vannan MA, Rubio-Guerra AF (2018) Echocardiographic measurements of epicardial adipose tissue and comparative ability to predict adverse cardiovascular outcomes in patients with coronary artery disease. Int J Cardiovasc Imaging 34:1429-1437

35. Mahabadi AA, Rassaf T (2018) Thoracic adipose tissue density as a novel marker of increased cardiovascular risk. Atherosclerosis 279:91-92

36. Shah RV, Anderson A, Ding J, Budoff M, Rider O, Petersen SE, Jensen MK, Koch M, Allison M, Kawel-Boehm N, Wisocky J, Jerosch-Herold M, Mukamal K, Lima JAC, Murthy VL (2017) Pericardial, but not hepatic, fat by CT is associated with CV outcomes and structure: the multi-ethnic study of atherosclerosis. JACC Cardiovasc Imaging 10:1016-1027

37. Kitagawa T, Yamamoto H, Hattori T, Sentani K, Takahashi S, Senoo A, Kubo Y, Yasui W, Sueda T, Kihara Y (2018) Tumor necrosis factor-alpha gene expression in epicardial adipose tissue is related to coronary atherosclerosis assessed by computed tomography. J Atheroscler Thromb 25:269-280

38. Du Y, Ji Q, Cai L, Huang F, Lai Y, Liu Y, Yu J, Han B, Zhu E, Zhang J, Zhou Y, Wang Z, Zhao Y (2016) Association between omentin-1 expression in human epicardial adipose tissue and coronary atherosclerosis. Cardiovasc Diabetol 15:90

39. Sanchis-Gomar F, Perez-Quilis C, Leischik R, Lucia A (2016) Epidemiology of coronary heart disease and acute coronary syndrome. Ann Transl Med 4:256

40. Oguntola SO, Hassan MO, Duarte R, Dix-Peek T, Dickens C, Olorunfemi G, Vachiat A, Paget G, Manga P, Naicker S (2018) Atherosclerotic vascular disease and its correlates in stable black South African kidney transplant recipients. Int J Nephrol Renovasc Dis 11:187-193

41. Cai G, Shi G, Xue S, Lu W (2017) The atherogenic index of plasma is a strong and independent predictor for coronary artery disease in the Chinese Han population. Medicine (Baltimore) 96(37):e8058

Publisher's Note Springer Nature remains neutral with regard to jurisdictional claims in published maps and institutional affiliations. 